\title{
IGCP 596, Mid-Paleozoic conodonts \& corals and the Mongolian Research Team in Europe
}

\author{
Thomas J. Suttner ${ }^{1,2}$ and Erika Kido ${ }^{2}$ \\ 1 Geological-Paleontological Department, Natural History Museum Vienna, Burgring 7, 1010 Vienna, Austria.E-mail: suttner.thomas@gmail.com \\ 2 University of Graz - Institute for Earth Sciences (Geology and Paleontology), Heinrichstrasse 26, 8010 Graz, Austria. \\ E-mail: erika.kido@uni-graz.at
}

\begin{abstract}
A new subproject of IGCP 596 (Climate change and biodiversity patterns in the Mid-Paleozoic) started in 2015. The Goal of the project is to increase the record of rugose coral biodiversity and to provide a high-resolution biostratigraphy especially of Devonian fossil-rich deposits in western Mongolia. A big step was achieved with the Conodont Workshop held in Graz, Austria (25.09-01.10.2015) exclusively for teaching conodont extraction techniques to colleagues from the Paleontological Center of the Mongolian Academy of Sciences (MAS) and the School of Geology and Petroleum Engineering of the Mongolian University of Science and Technology (MUST). With the knowledge provided during the workshop, in both microfossil laboratories at the MAS and at the MUST units for conodont extraction were established.
\end{abstract}

\section{Introduction}

A new research project within the Austrian Academy of Sciences Research Programme Earth System Sciences (ESS) has started. It is related to the International Geoscience Programme (IGCP) and supports the research activity of IGCP 596, which primarily focus on climate change and biodiversity patterns in the Mid-Paleozoic (Early Devonian to Late Carboniferous). The actual ESS project concerns conodont biostratigraphy and occurrence data of Mid-Paleozoic corals in Mongolia and Europe (Project duration: two years). The basic idea for this project grew during fieldtrips in western Mongolia in 2012 and 2014 (Kido et al., 2013; Ariunchimeg et al., 2014), when we realized the close affinity of the Late Devonian sedimentary sequence to coeval deposits in North China (Carmichael et al., 2014, 2015). Since the beginning of our collaboration, a strong international coregroup has developed that, to date, includes about 20 scientists from Austria, Belgium, Czech Republic, Germany, Mongolia, Russia, Spain, UK and USA. Several members of the group are also involved in the DAGGER Project (Devonian, Anoxia, Geochemistry, Geochronology \& Extinction Research) housed at Appalachian State University (Team Leaders: Sarah Carmichael and Johnny Waters; website: http://devonian.appstate.edu/).

Fieldwork in western Mongolia resulted in large fossil collections including plants, corals, trilobites, crinoids, brachiopods and bryozoans. However, no microfossil biostratigraphy has been applied until now. Thus, a proper age determination of the Devonian sedimentary sequence in western Mongolia for further biodiversity study of macrofossils is one of the major tasks of this project.

\section{IGCP 596 Symposium in Brussels}

Preceding the stay in Austria for the Conodont Workshop (25.0901.10.2015), the Mongolian research team participated in the fifth annual IGCP 596 and SDS joint meeting in Brussels (20.0922.09.2015). With ten contributions, presented within the framework of theirown topically focused session on Mongolian Paleozoic strata, attendance was high during the symposium in Brussels which was attended by 100 participants from 19 countries.

\section{Conodont Workshop}

After arrival in Vienna from Brussels, the entire group spent one day in Vienna, linked with a visit at the Geological Survey of Austria (Fig. 1). Thomas Hofmann, head of the library, gave an overview on the history of the Geological Survey and summarized activities of some of the most important geologists of Austria; among them Franz Ritter von Hauer, who compiled the geological map of the AustroHungarian Monarchy (1867-1871). Additionally, Hofmann guided the group through the library and archive which contains one of the biggest collections of Geoscience-related literature in central Europe.

On the next day, the entire group moved to Graz for the Conodont Workshop which was organized by Erika Kido, Thomas J. Suttner and Werner E. Piller at the Institute for Earth Sciences (University of Graz). Participants of the course, all women scientists, were Ariunchimeg Yarinpil and Uugantsetseg Byambajav from the Paleontological Center of the Mongolian Academy of Sciences and Sersmaa Gonchigdorj, Ariuntogos Munkhjargal and Manchuk Nuramkhaan from the School of Geology and Petroleum Engineering of the Mongolian University of Science and Technology (Fig. 2).

The Mongolian team experienced all steps of conodont extraction in three days of laboratory work, starting from sample arrangement, via preparation of limestone and marls for acid bath immersion in formic acid under slightly differing concentrations, towet sieving. Laboratory work was followed by a general lecture on conodonts including a microscope tutorial for picking conodonts from insoluble residues and mounting of specimens on SEM stubs (Fig. 3).

For taxonomic training on Frasnian and Famennian conodont taxa, twenty conodont samples, collected from well-known Late Devonian pelagic limestones of the Wolayer Glacier section in the Carnic Alps (Schönlaub, 1980), were dissolved. At the end of the workshop, participants were able to discriminate at least four different conodont genera: Ancyrognathus, Icriodus, Palmatolepis and Polygnathus.

A second task of the workshop concerned sustained preservation of taxonomic knowledge of Devonian corals from western Mongolia. A detailed search in online databases, like the Paleobiology Database, showed that most of taxonomic publications on Devonian corals from Mongolia have not yet been entered. Ulitina (2001), for example, reported rugose corals from the Baruunhuurai Formation cropping out in the vicinity of the Zagiin-Hara-Uul Mountains, west of IhShovgor Mountain and on the southern slope of the Indrengiin-Nuruu Range (different localities from those of our research group). Plots of these and other coral occurrences do not appear on the paleogeographic reconstruction of the Paleobiology Database navigator. Subsequent updating of the database will strongly profit from the knowledge on Mongolian coral literature (published by Mongolian and Russian workers) of one member of the invited 

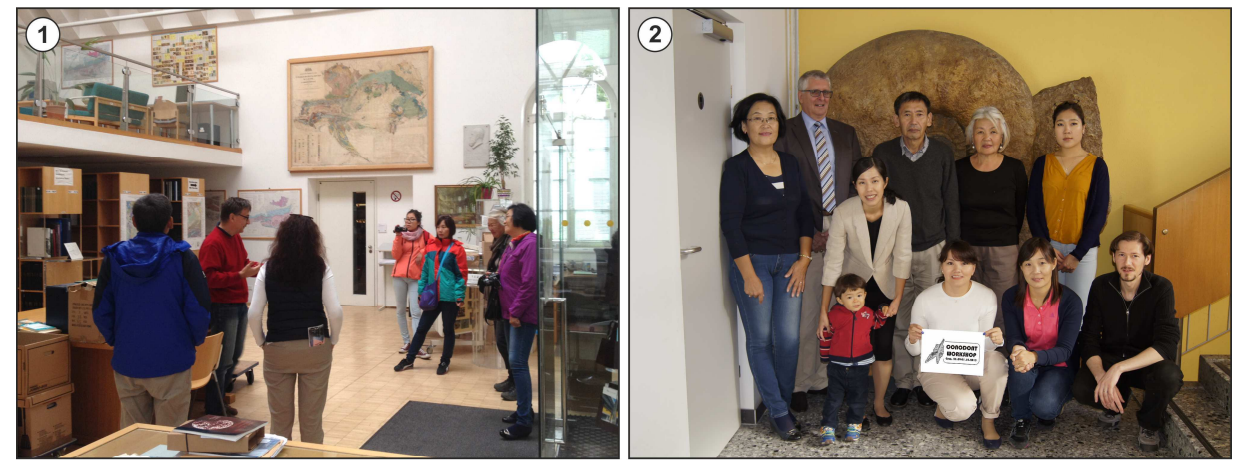

introduction to conodont taxonomy) enables our colleagues to teach the technique of conodont extraction to students. Within the frame of the IGCP 596 subproject and further collaboration in future, we will support them to educate students and scientists from Mongolia in conodont biostratigraphy.

\section{Acknowledgements}

Expenses for both meetings were met
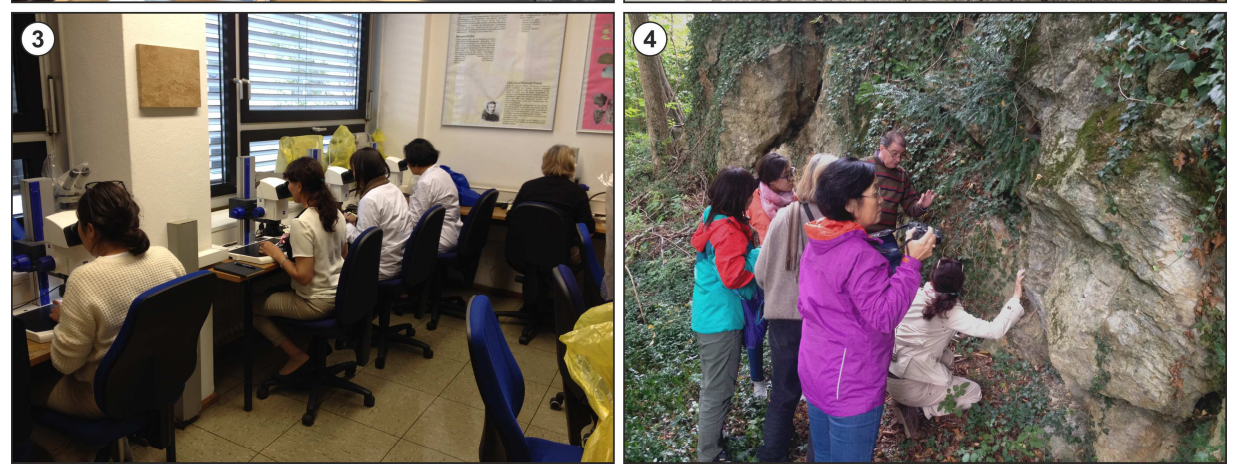

entirely by the IGCP 596 subproject (Austrian Academy of Sciences, ESS). The Austrian Science Fund is acknowledged by the authors, because grants from project FWF P 23775-B17 set the basis for this, already four years long, and lasting collaboration. Thomas Hofmann (Geological Survey of Austria) is thanked for guiding the group through the Geological Survey. Bernhard Hubmann (University of Graz) isthanked for guiding an exciting excursion to Devonian outcrops of the Graz Paleozoic. This article represents one more highlight of the Austria (Vienna) guided by Thomas Hofmann. 2: Conodont Workshop (Graz). Group photo (back row, left to right: Werner E. Piller, Purevbaatar Munkhbat [accompanying person], Ariunchimeg Yarinpil, Ariuntogos Munkhjargal; front row, left to right: Sersmaa Gonchigdorj, Erika Kido, Akito J. Suttner [accompanying person], Manchuk Nuramkhaan, Uugantsetseg Byambajav, Thomas J. Suttner). 3: Conodont extraction procedure applied on conodont-rich Late Devonian limestone samples from the Carnic Alps (lecture room of the Institute for Earth Sciences, University of Graz). 4: Field trip to the D/C-boundary at Quarry Trolp guided by Bernhard Hubmann.

international cooperation between Austrian and Mongolian researchers within the framework of IGCP 596 and is dedicated to Minjin Chuluun who sadly passed away in 2015. He was an outstanding scientist and a pioneer in fostering international

research team, who is a tabulate coral specialist. Via the online Paleobiology Database, it will become easy to distribute and share results from this project on coral taxa and their age (calibrated by conodonts) with Paleozoic coral researchers globally. After the presentation by E. Kido, who summarized most important tools for entering taxonomic datasets into the Paleobiology Database, the Mongolian team set the next step and started to prepare a list of Devonian coral literature from Mongolia.

On the last day of the workshop, Bernhard Hubmann (University of Graz) guided an excursion to some Devonian localities of the Graz Paleozoic succession (Fig. 4). The first stop of the field trip was at the top of Mount Plabutsch, where the Mongolian team received an overview on the sedimentary development of the Graz Paleozoic (Silurian to Carboniferous). Then the group visited other two localities that are known as representative outcrops in the Graz Paleozoic (Hubmann \& Gross, 2015) for (1) Middle Devonian shallow marine deposits (Locality: Forest road Attems) and (2) Late Devonian to Mississippian deeper marine sediments including the Devonian/ Carboniferous-boundary interval (Locality: Quarry Trolp).

\section{Results}

Soon after the Mongolian team returned back to Ulaanbaatar, they finalized the adaptation of laboratory facilities for conodont processing in microfossil laboratories of the MAS and MUST. With the support given, they are now able to independently process limestone samples for conodonts.. All the background information provided during the workshop (e.g. web-links to providers of specific laboratory facilities, conodont literature and a basic collaboration for joint fieldwork in Mongolia.

\section{References}

Ariunchimeg, Y, Bayasgalan, A., Waters, J.A., Kido, E., Suttner, T.J., Sersmaa, G., Undariya, J. and Otgonbaatar, D. (eds), 2014, IGCP 596 IGCP 580 Field Workshop Guidebook. 8-18 August, Ulaanbaatar, Mongolia: Paleontological Center, Mongolian Academy of Sciences, pp. 1-55.

Carmichael, S.K., Waters, J.A., Batchelor, C.J., Coleman, D.M., Suttner, T.J., Kido, E., Moore, L.M. and Chadimová, L., 2015, Climate instability and tipping points in the Late Devonian: Detection of the Hangenberg Event in an open oceanic island arc in the Central Asian Orogenic Belt: Gondwana Research, online first, http://dx.doi.org/10.1016/ j.gr.2015.02.009

Carmichael, S.K., Waters, J.A., Suttner, T.J., Kido, E. and DeReuil, A.A., 2014, A new model for the Anoxia Events (Late Devonian): Shallow water anoxia in an open oceanic setting in the Central Asian Orogenic Belt: Palaeogeography, Palaeoclimatology, Palaeoecology, 399, pp. 394 403, doi:10.1016/j.palaeo.2014.02.016

Hubmann, B. and Gross, M., 2015, The vicinity of Graz: Upper Silurian to upper Carboniferous of the Graz Palaeozoic, upper Cretaceous of the Kainach Gosau and middle Miocene of Gratkorn: Berichte der Geologischen Bundesanstalt, 111, pp. 41-74.

Kido, E., Suttner, T.J., Waters, J.A., Ariunchimeg, Y., Sersmaa, G., Atwood, J.W. and Webster, G.D., 2013, Devonian deposits of the Baruunhuurai Terrane, western Mongolia (IGCP 596 Field Workshop): Episodes, 36 (4), pp. 242-254.

Schönlaub, H.P., 1980, Carnic Alps. Field Trip A. with contributions from Jaeger, H., House, M.R., Price, J.D., Göddertz, B., Priewalder, H., Walliser, O.H., Køí•, J., Haas, W. and Vai, G.B. - In: Schönlaub, H.P. (ed.): Second European Conodont Symposium, ECOS II, Guidebook, Abstracts: Abhandlungen der Geologischen Bundesanstalt, 35, pp. 5-57.

Ulitina, L.M., 2001, Frasnian Rugosa from Mongolia: Paleontological Journal, v. 35 , no. 2 , pp. $125-129$. 